\title{
Dietry Impact of Normal and Germinated Barely Products on body weight and Lipid Profile of Diabetic Rats
}

\author{
Tesby M. R. Lotfy ${ }^{1}$, Neveen. F. Agamy ${ }^{2}$, Nashwa. M. Younes ${ }^{1}$
}

\begin{abstract}
The present study aimed to evaluate the effect of barely grains and germinated barely products on lipid profile and lipoprotein of diabetic rats. Male albino rats $(n=56)$ were divided into two main groups, the first group ( $n=7$ rats) considered as a control negative group (G1). The remaining 49 rats were injected with Alloxan $(120 \mathrm{mg} / \mathrm{kg}$ BW) for the induction of diabetes, then were divided into (7) subgroups ( $n=7$ rats for each), the first subgroup was left without treatment and considered as a control positive group (G2). G3 Diabetic rats were fed on normal barely bread, G 4 Diabetic rats were fed on germinated barely bread, G 5 Diabetic rats were fed on normal barely biscuits, G 6 Diabetic rats were fed on germinated barely biscuits, G7 Diabetic rats were fed on normal barely talbina, G 8 Diabetic rats were fed on germinated barely talbina. After 4 weeks, the mean values of body weight was estimated in all groups. Blood samples were collected to estimate lipid profile including cholesterol, triglycerides, LDL-c, and HDL-c. The results showed that there were a significant loss body weight for rats fed on germinated barely products compared to control possitive. Rats fed on germinated barely products exhibited lower glucose in contrary to insulin and improvement of enzymes activity to level comparable to the normal level. Results also revealed that, feeding rats on germinated barely products such as bread, biscuits and talbina led to significant decrease in serum cholesterol, triglycerides, LDL-c, and increase HDL-c. As conclusion, germinated barely products especially germinated talbina had improved the lipid profile compared with the control. Our results recommended germinated barely could be as functional foods to improve human health.
\end{abstract} profile.

Key words: diabetes, barely, germinated barely, lipid

\section{INTRODUCTION}

In the last decade the search for functional foods has been widely encouraged by food companies. Consumers demand of new food products not only to satisfy a physiological need but also to have healthy food with necessary nutrients to prevent nutrition-related diseases and to improve physical and mental health. In this regard, a close relation between nutrition and health has been established and functional foods containing ingredients with a specific health benefit were technologically developed as reported by Niva (2007).

Functional foods contain biologically active ingredients associated with physiological health benefits for preventing and managing chronic diseases, such as type 2 diabetes mellitus (T2DM). A regular consumption of functional foods may be associated with enhanced anti-oxidant, anti-inflammatory, insulin sensitivity, and anti-cholesterol functions, which are considered integral to prevent and manage T2DM (Alkhatib et al., 2017). Although there is no consensus on the exact definition of the "functional food" term, according to the American Dietetic Association, functional food is defined as "any modified food or food ingredient that may provide a health benefit beyond that traditional nutrients that contains (Coles, 2014). Recently, Functional Food Center (FFC) has defined functional food as follows: Natural or processed foods that contain known or unknown biologically- active compounds; which defined amounts provide a clinically proven and documented health benefit for the prevention, management, or treatment of chronic disease (Martirosyan and Singh, 2015). Therefore, The objective of study is to investigate the effect of some normal and germinated barely products on the body weight and determine the role of them on the lipid profile of diabetic rats.

Diabetes mellitus is a chronic disorder of carbohydrate, lipid and protein metabolism manifested by elevated blood glucose level. This disease is caused by a defect in cellular uptake of glucose due to either reduced insulin secretion or cellular resistance to insulin (Hughs et.al. 1984; DeFronzo, 1997). Clinically, diabetes is an important risk factor for a range of diseases including nephropathy, retinopathy and neuropathy, and it is increasing in prevalence according to some estimates (Tripathi and Srivastava, 2006). In addition, lipid disorders and lipid per-oxidation together with diabetes play a crucial role in the development of cardiovascular disease (Stocker \& Keaney, 2004. Although, insulin and hypoglycaemic drugs constitute the main treatment in diabetes, the use of nutritional methods and medicinal

\footnotetext{
DOI: 10.21608/asejaiqjsae.2021.152592

${ }^{1}$ Home Economics Department, Faculty of Specific Education,

Alexandria University, Alexandria, Egypt.

${ }^{2}$ Department of nutrition, High Inistitute of Public Health,

Received January20, 2021, Accepted, February 28, 2021.
} 
plants are increasing in some countries (Grover et.al. 2002)

The chronic hyperglycemia of diabetes is associated with long-term damage and failure of various organ systems mainly affecting eyes, nerves, kidneys, and the heart. Nephropathies, retinopathies, neuropathies, ischemic heart diseases, peripheral vascular diseases, and cerebrovascular diseases (Chawla et al., 2016).

The prevalence of (T2DM) is increasing at an alarming rate worldwide, causing a significant increase in premature mortality, co-morbidity, and increased healthcare costs. The future predictions are also gloomy given that 1 in 10 people worldwide is expected to have the condition by 2030, Common determinants include excess body fat, poor diet, physical inactivity, high blood pressure, and family history of diabetes (WHO., 2016).

Consumption of foods rich in fiber is recommended for nutritional therapy of diabetes (Nader et al., 2014). Anti-diabetic effects of foods, including soluble fibers, have become a focus of interest for many researchers (Li et al., 2020).

"Cereal grains make up a major part of most people's diets and they are described as "whole grain" if all components of the kernel (the bran, germ, and endosperm) are still present in their natural proportions" (Slavin et al., 2001). There was a good evidence that consumption of whole grains may reduce the risk of diabetes (Montonen et al., 2003).

Barely is gaining more interest due to its nutritional value, especially because of the dietary fiber content and the presence of non-starch polysaccharides, barely is a rich source fiber providing beneficial (Pejcz et al., 2016).

Germination is a process in which physical modification of endosperm is carried out to increase the bioactive compounds. During germination, starch degradation is very limited, despite the fact that starch degrading enzymes are synthesized. The total protein content of cereals increases slightly during germination due to more intensive degradation of other kernel components for respiration (Kaukovirta-Norja et al., 2004).Germination process leads to structural modification and synthesis of new compounds with high bioactivity and can increase the nutritional value and stability of grains (Nonogaki.,2010).

\section{Research Problem}

Diabetes mellitus and its related complications are the serious public health concern globally. The prevalence of type 2 diabetes is rapidly increasing worldwide, in 2010, the global prevalence of (T2DM) was estimated at $8.3 \%$ of adult population, proportion that is projected to increase to $9.9 \%$ by 2030 . As this harmful effect of (T2DM)on health, Serious long-term complications include cardiovascular disease, stroke, kidney failure, foot ulcers and damage to the eye. Conventional treatment may cause many side effects and sometimes becomes less effective in controlling type $2 \mathrm{DM}$. Therefore there is an increasing demand for changing life style and incorporating low glycemic index food that affect the glucose level and also may reduce the amount of consumed carbohydrates that can be a direct cause of increasing type 2 DM. Barley contains very high levels of dietary fiber relative to other cereal grains, offering potential as a postprandial glycemic response lowering agent for the growing number of individuals trying to manage blood glucose levels and lipid profile. The objective of this study was to investigate the effect of some normal and germinated barely products on the body weight and determine the role of them on the lipid profile of diabetic rats.

Therefore, this study focused on:

- Preparing barely products including normal and germinated barely bread, biscuits as well as normal and germinated talbina.

- Determining the role of barely and germinated barely as hypoglycemic agent on diabetic rats

\section{MATERIALS AND METHODS}

\section{Materials:}

Ten kilograms of each varieties of Egyptian barely grain (Hordeum Vulgare) (50\%Giza 126 and 50\% Giza 132) were purchased from Farm College of Agriculture, Alexandria University. Other components (butter, sugar, salt, eggs, vanill and baking powder which were used in the preparing products were purchased from local markets in Alexandria, Egypt.

\section{Chemicals and Kits}

- All used chemicals and reagents were analytical grade and obtained from EL- Goumhorya Company, Egypt.

- Alloxan was dissolved in saline solution $(0.9 \%$ sodium chloride,pH7). The dose of Alloxan used was 120 $\mathrm{mg} / \mathrm{kg}$ BW/day. The Chosen dose of Alloxan is well documented to induce diabetes in rats according the previous studies of Mansour et al. (2002). Commercial Kits were obtained from Biosystems S.A.(Spain), Diamond(Germany)and Randox (United King dom).

\section{Animals:}

56 male albino rats of Westar strain were used in the present experiment, weighing $150-180 \mathrm{gm}$ were obtained from Institute of Graduate Studies and Research, Alexandria University. Rats were housed in wire cages under the normal laboratory conditions and were fed on 
basal diet for two weeks as an adaptation period. Food and water provided ad-labitum and checked daily.

\section{Methods:}

\section{Preparing barely products}

Barely products were prepared according to Saba (1991) methods.

\section{Preparing of barely bread}

Dough was prepared by using the following formula: $400 \mathrm{gm}$ normal barely flour without additives, $2 \mathrm{~g}$ sugar, $2.25 \mathrm{~g}$ salt, $15 \mathrm{~g}$ yeast, $200 \mathrm{~g}$ water. Dough was prepared by adding all the dry ingredients together (flour, salt, dry yeast and sugar). Then adding warm water slowly until you get afirm dough. Dough has been put in a warm place for 30 min till fermentation. Cut the dough into rounded pieces and spread the dough and shape like acircle. put dough another time for $20 \mathrm{~min}$ till fermentation. Bake it in the preheated $200^{\circ} \mathrm{C}$ oven on hot stone for 8 minutes until it rises (Saba,1991).

\section{Preparing of barely biscuits:}

Biscuits were prepared by using the following formula: $250 \mathrm{~g}$ barely flour, $150 \mathrm{gm}$ shortening, $45 \mathrm{~g}$ eggs, $3 \mathrm{~g}$ baking powder,7g salt. The margarine was creamed until light and fluffy. Salt was added, and the mixture was creamed a little more. The eggs were added and the liquid components were beaten together for a while. It was added to the creamed mixture and were beaten together. Then, the flour and the baking powder were sieved together, and folded into the creamed mixture. The dough was cut into small shapes and baked. These were baked at oven temperature of $170^{\circ} \mathrm{C}$ for 15 mins. After baking, biscuits were packed in tray pans (Saba, 1991).

\section{Preparing of Talbina}

Talbina was prepared by adding barely flour to water $(1: 10 \mathrm{w} / \mathrm{v})$ then the mix was heated at $80^{\circ} \mathrm{C}$ for five minutes with continuous stirring until reaching a pporidge like texture (Youssef, 2008).

\section{Preparing of Germinated Barely}

Grains were freed from broken seeds, dust and foreign materials, and then soaked in water for 12 hours. The pre- soaked seeds were spread on wet cotton in aluminium baskets for 3-4 days until germinated seeds then, the germinated seeds were dried on air for 48 hours (Youssef et al., 2013).

\section{Preparing of germinated talbina}

Talbina was prepared by adding germinated barely flour to water $(1: 5 \mathrm{w} / \mathrm{v})$ then the mix was heated at $80^{\circ} \mathrm{C}$ for five minutes with continuous stirring until reaching a pporidge like texture (Youssef, 2008).

\section{Preparing of germinated barely bread:}

Dough was prepared by using the following formula: $500 \mathrm{~g}$ germinated barely flour with additives $5 \mathrm{gm}$ guar gum, 1g sugar, $2.25 \mathrm{~g}$ salt, $15 \mathrm{~g}$ yeast, $200 \mathrm{~g}$ water. Dough was prepared by adding all the dry ingredients together (flour, salt, dry yeast and sugar). Then adding warm water slowly until you get afirm dough. Dough has been put in a warm place for $30 \mathrm{~min}$ till fermentation. Cut the dough into rounded pieces and spread the dough and shape like acircle. put dough another time for $20 \mathrm{~min}$ till fermentation. Bake it in the preheated $200^{\circ} \mathrm{C}$ oven on hot stone for 8 minutes until it rises. Adding guar to be forming process dough easy (Saba, 1991).

\section{Preparing of germinated barely biscuits:}

Biscuits were prepared by using the following formula: $250 \mathrm{~g}$ germinated barely flour, $150 \mathrm{gm}$ shortening, $45 \mathrm{~g}$ egg, $3 \mathrm{~g}$ baking powder,7g salt. The margarine was creamed until light and fluffy. Salt was added, and the mixture was creamed a little more. The eggs were added and the liquid components were beaten together for a while. It was added to the creamed mixture and were beaten together. Then, the flour and the baking powder were sieved together, and folded into the creamed mixture. The dough was cut into small shapes and baked. These were baked at oven temperature of $170^{\circ} \mathrm{C}$ for 15 mins. After baking, biscuits were packed in tray pans (Saba, 1991).

\section{Experimental Design}

A total of 56 male Albino rats of wistar strain (150$180 \mathrm{~g}$ ) were used in this experiment. 7 rats were left as control (Group 1) fed on basal diet. The remain 49 rats were injected with Alloxan (120mg/kg BW)for the induction of diabetes. Rats were left for one week till stabilization of diabetes then divided randomly into 7 equal groups as follows:

Group 2: Diabetic rats fed on basal diet

Group3: Diabetic rats fed on bread made of barely grains.

Group 4: Diabetic rats fed on bread made of germinated barely grains.

Group5: Diabetic rats fed on biscuits made of barely grains.

Group6: Diabetic rats fed on biscuits made germinated barely grains

Group7: Diabetic rats fed on talbina made of barely grains.

Group8: Diabetic rats fed on talbina made of germinated barely grains.

After the experimental period (4 weeks), Rats were fasted overnight, sacrified, blood samples were withdrawn and serum were prepared for the analysis: 
Blood glucose level, Lipid profiles of rats . All animals were sacrificed at the end of the experiment.

-Laboratory Analysis:

Blood sampling:

At the end of experimental period rats were fasted over night before sacrificing. Blood collected and serum separated and used for measuring lipid profile (total cholesterol, Triglyceride, high and low density lipoprotein-cholesterol (HDL-c and LDL-c), and body was also weighed.

\section{Determination of lipid profile in serum}

Triglyceride was determined as described by Fossati and Prencipe (1982), the enzymatic colorimetric GPOPAP kit was used for the measurement of triglycerides after enzymatic hydrolysis with lipase. Total cholesterol was determined according to Richmond (1973). High density lipoprotein (HDL) was determined according to Lopes-Virella et al. (1977), Low density lipoprotein LDLcholesterol was determined according to the method of Jaye et al. (2009).

\section{Determination of glucose}

Quantative determination of glucose was carried out according to the method of (Lott and Turner 1975).

\section{Statistical analysis}

Data were analyzed using IBM SPSS software package version 20.0. (Armonk, NY: IBM Corp). Quantitative data was described using mean, standard error and standard deviation. Significance of the obtained results was judged at the 5\% level. Student ttest used for normally distributed quantitative variables, to compare between two studied groups and F-test (ANOVA) used for normally distributed quantitative variables, to compare between more than two groups, and Post Hoc test (LSD) for pairwise comparisons (Kirkpatrick \& Feeney, 2013).

\section{RESULTS AND DISCUSSION}

\section{Body and organ weights of rats}

With the rapidly increasing prevalence of diabetes and its high economic burden in the world population, the scientific community has been called upon to develop new safer and inexpensive medicines for the treatment of diabetes. Therefore, various studies have been recently conducted to recognize the anti-diabetic potential of barely and its component (Yousef et.al. 2006).

It is worth to mention that alloxan was used to induce diabetes in the rats. Alloxon establishes a redox cycle with the formation of superoxide radicals. These radicals undergo dimcutation to hydrogen peroxide and hence highly reactive hydroxyl radical are formed by the Fenton reaction. The action of reactive oxygen species (ROS) with simultaneous massive increase in cytosolic calcium concentration causes rapid destruction of $\beta$-cells of the rat pancreas (Szkudelski, 2001).

Table (1) revealed that body weight of rats belonging to the positive control was significantly $(\mathrm{p} \leq 0.05)$ lower $(160 \mathrm{gm})$ than its counterparts of the negative control $(175 \mathrm{gm})$. It was obvious that body weights of rats belonging to different groups varied significantly $(\mathrm{p} \leq 0.05)$. These groups can be ascending ordered as follows, (in/gm): Negative control (175), rats fed on barely bread (170), rats fed on germinated barely bread (177); rats fed barely biscuits (175), rats fed on germinated barely biscuits (187), rats fed on talbina (175) and finally rats fed on germinated talbina (180) as presented.

Liver weight for the negative control was found to be $2.80 \mathrm{gm}$. The positive control possessed the highest liver weight. No significant differences in terms of weight of rats liver could be detected for rat fed on barely bread, rats fed on germinated barely bread rats fed on barely biscuits, germinated barely biscuits, rats fed on talbina,rats fed on germinated talbina respectively as shown in Table (1).

Data presented in Table (1) show that lung weight of rats belonging to the positive control was significantly $(\mathrm{p} \leq 0.05)$ higher than that for the other rat groups including the negative control being gm.It is worth to note that the weight of rat brain for all rat groups were not significantly different from each other. However all these groups were significantly different from the negative control as shown in Table1. The positivecontrol rats exhibited significantly the highest heart weight $(\mathrm{gm})$. Meanwhile, the negative control rats recorded significantly the highest testes weight (gm). In contrast, the positive control had significantly the least testes weight (gm). 
Table 1.Changes in body and body organs weight $(\mathrm{BW} / \mathrm{gm})$, and relative weight (g/100) of diabetic and non-diabetics rats treated

\begin{tabular}{|c|c|c|c|c|c|c|c|c|c|}
\hline Treatment groups & Body weight & Liver & Kidney & Heart & Lung & Brain & Tests & Spleen & Pancreas \\
\hline Control (-) & $175.0^{\mathrm{bc}} \pm 2.75$ & $2.80^{\mathrm{a}} \pm 0.04$ & $0.77^{\mathrm{a}} \pm 0.01$ & $0.40^{\mathrm{ab}} \pm 0.03$ & $0.79^{\mathrm{b}} \pm 0.05$ & $1.06^{\mathrm{b}} \pm 0.03$ & $1.33^{\mathrm{a}} \pm 0.08$ & $0.36^{a} \pm 0.03$ & $0.36^{a} \pm 0.03$ \\
\hline Diabetic rats & $160.0^{\mathrm{d}} \pm 3.53$ & $3.53^{\mathrm{a}} \pm 0.07$ & $1.06^{\mathrm{a}} \pm 0.03$ & $0.52^{\mathrm{a}} \pm 0.04$ & $1.09^{\mathrm{a}} \pm 0.12$ & $1.30^{\mathrm{a}} \pm 0.02$ & $1.09^{\mathrm{bc}} \pm 0.07$ & $0.39^{\mathrm{a}} \pm 0.04$ & $0.29^{\mathrm{ab}} \pm 0.01$ \\
\hline D +barely bread & $170.0^{c} \pm 2.45$ & $2.82^{\mathrm{a}} \pm 0.21$ & $0.93^{\mathrm{a}} \pm 0.09$ & $0.35^{\mathrm{b}} \pm 0.03$ & $0.79^{\mathrm{b}} \pm 0.03$ & $0.94^{\mathrm{bc}} \pm 0.01$ & $0.85^{\mathrm{a}} \pm 0.06$ & $0.20^{\mathrm{b}} \pm 0.02$ & $0.25^{\mathrm{b}} \pm 0.02$ \\
\hline D +Germinated barely bread & $177.0^{\mathrm{bc}} \pm 3.94$ & $2.90^{\mathrm{a}} \pm 0.09$ & $0.90^{\mathrm{a}} \pm 0.04$ & $0.33^{\mathrm{b}} \pm 0.06$ & $0.73^{b} \pm 0.05$ & $0.92^{\mathrm{bc}} \pm 0.02$ & $0.83^{\mathrm{d}} \pm 0.07$ & $0.22^{\mathrm{b}} \pm 0.03$ & $0.23^{b} \pm 0.03$ \\
\hline D +barely biscuits & $175.0^{\mathrm{bc}} \pm 2.21$ & $3.15^{\mathrm{a}} \pm 0.14$ & $0.82^{\mathrm{a}} \pm 0.09$ & $0.38^{\mathrm{b}} \pm 0.04$ & $0.74^{\mathrm{b}} \pm 0.05$ & $0.88^{\mathrm{c}} \pm 0.07$ & $1.15^{\mathrm{ab}} \pm 0.07$ & $0.24^{\mathrm{b}} \pm 0.05$ & $0.24^{\mathrm{b}} \pm 0.03$ \\
\hline $\mathrm{D}+$ germinated barely biscuits & $187.0^{\mathrm{a}} \pm 3.59$ & $2.72^{\mathrm{a}} \pm 0.38$ & $0.86^{\mathrm{a}} \pm 0.04$ & $0.32^{\mathrm{b}} \pm 0.04$ & $0.75^{\mathrm{b}} \pm 0.05$ & $0.87^{\mathrm{c}} \pm 0.03$ & $0.81^{\mathrm{d}} \pm 0.07$ & $0.23^{\mathrm{b}} \pm 0.04$ & $0.26^{\mathrm{b}} \pm 0.02$ \\
\hline $\mathrm{D}+$ Talbina & $175.0^{\mathrm{bc}} \pm 2.51$ & $3.20^{\mathrm{a}} \pm 0.14$ & $0.74^{\mathrm{a}} \pm 0.09$ & $0.34^{\mathrm{b}} \pm 0.04$ & $0.67^{\mathrm{b}} \pm 0.08$ & $0.86^{\mathrm{c}} \pm 0.14$ & $0.94^{\text {bcd }} \pm 0.08$ & $0.24^{\mathrm{b}} \pm 0.04$ & $0.24^{\mathrm{b}} \pm 0.03$ \\
\hline $\mathrm{D}+$ germinated talbina & $180.0^{\mathrm{ab}} \pm 3.25$ & $3.02^{\mathrm{a}} \pm 0.09$ & $0.88^{a} \pm 0.06$ & $0.35^{\mathrm{b}} \pm 0.07$ & $0.73^{b} \pm 0.05$ & $0.88^{\mathrm{c}} \pm 0.03$ & $0.94^{\mathrm{cd}} \pm 0.07$ & $0.23^{\mathrm{b}} \pm 0.03$ & $0.25^{\mathrm{b}} \pm 0.02$ \\
\hline $\mathrm{F}$ & $6.340^{*}$ & 2.305 & 2.409 & 1.900 & $3.906^{*}$ & $6.608^{*}$ & $6.737^{*}$ & $3.956^{*}$ & $3.032^{*}$ \\
\hline $\mathrm{P}$ & $0.001^{*}$ & 0.079 & 0.069 & 0.136 & $0.011^{*}$ & $0.001^{*}$ & $0.001^{*}$ & $0.011^{*}$ & $0.031^{*}$ \\
\hline LSD $5 \%$ & 9.254 & 0.5288 & 0.1934 & 0.140 & 0.1949 & 0.1754 & 0.2105 & 0.1038 & 0.073 \\
\hline
\end{tabular}

Data was expressed using Mean \pm SE.

F: F for ANOVA test, Pairwise comparison bet. each 2 groups was done using Post Hoc Test (LSD)

Means in the same column with common letters are not significant (i.e. Means with Different letters are significant)

p: $p$ value for comparing between the studied groups

*: Statistically significant at $\mathrm{p} \leq 0.05$

D:Diabetic rats 
No significant differences in testes weight could be figured out among the different groups of rats .Kidney weight had significantly $(\mathrm{p} \leq 0.05)$ the highest $(\mathrm{gm})$ for the positive control group on contrary to the rat group fed on normal and germinated barely, which exhibited the least kidney weigh (gm). However, no significant differences $(\mathrm{p} \geq 0.05)$ could be traced among the other rat groups as shown in Table1.

It was clear that rats fed on each of germinated talbina had significantly $(\mathrm{p} \leq 0.05)$ the least spleen weights. On the other hand, pancreas weight were found to be significantly different $(\mathrm{p} \leq 0.05)$ with an exception of the negative control rat group as presented in Table 1.

According to the present study, it was obvious that diabetic rats fed on barely products exhibited significantly $(\mathrm{p} \leq 0.05)$ improvement in organ weights as follows: Rats fed on germinated talbina (Liver and lung), rats treated with talbina, rats fed on germinated barely (testes), rats fed on germinated biscuits (kidney), rats fed on barely bread (kidney and spleen) and rats fed germinated bread (pancreas). These data are in agreement of that found by other researches (Yousef et.al. 2006).

\section{Body weight of rat feed on normal and germinated barely products for four weeks}

Table (2) and Figure (1) showed the mean body weight after treatingrat on normal and germinated barely products (bread, biscuits and talbina) for four weeks. The body weight increased with increasing feeding weeks, whether in diabetic rats. At the second week of feeding on the basal diet, the average of rat body weight was $155.0 \mathrm{~g}$ with percent of increase (3.33\%) corresponding to the mean body weight of rat at first week. While in diabetic rats, the average was $180.07 \mathrm{~g}$ with decreased percent $(2.78 \%)$ of rat at first week. In the fourth and last week of feeding on the basal diet, the average of rat body weight was $175.0 \mathrm{~g}$ with percent of increase $(16.67 \%)$ corresponding to the mean body weight of rat at first week. While in diabetic rats, the average was $160.0 \mathrm{~g}$ with decreased percent $(11.11 \%)$ of rat at first week. The data showed that the body weight of diabetic rats treated with normal and germinated barely products decreased compared to control possitive. The rate of decrease of body weight of rat that treated on germinated talbina during 4 weeks were $2.01,6.03,9.55 \%$. our results are in agreement with Yawen Zeng et al 2020\& Y. Zeng et al 2018 who reported that barely and germinated barely had stronger effects in lowering body weight and Obesity resistance.

\section{Glucose and insulin in serum of rats:}

Data in Table(3) indicated that the diabetic rats had significantly higher $(\mathrm{p} \leq 0.05)$ serum glucose and lower insulin than the healthy rats the negative control.It was clear that the diabetic rats fed on germinated and normal barely products respectively exhibited significantly lower $(\mathrm{p} \leq 0.05)$ plasma glucose than the diabetic group of rats.Germinated products due to its higher fiber content was found to be superior in lowering plasma glucose and elevating insulin of the diabetic rats, followed by normal barely products while tailed behind.

In the oral glucose tolerance test, germinated barely fed rats maintained a lower glucose level than rats fed on normal products It is worthy to mention that the compounds considered to be effective in improving glucose tolerance and contained fibers especial $\beta$ glucan (Brockman et al., 2013). Insulin levels were shown to be significantly lower $(\mathrm{p} \leq 0.05)$ in diabetic control group as compared to normal control group. Rats fed on germinated talbina ,bread, biscuits and normal products tailed behind, significantly $(\mathrm{p} \leq 0.05)$ increased insulin levels when compared with diabetic control group $(\mathrm{P} \leq 0.05)$.In this respect, germinated and barely products were found to increase blood insulin. Data presented here confirm the conclusion of (Asgary et. al. 2011; Mohajeri et. al. 2009). Astudy in alloxaninduced diabetic rats indicated that germinated and normal barely polysaccharides effective component had significantly hypoglycemic action (Xiong and Cao, 2001; Quanhong et.al. 2005) (XueMin \& Jue, 2001; Quanhong et al., 2005).

The increase in serum glucose level of rats treated with alloxan is consistent with the finding of Suresh and Das (2006) who noted a significant increase in the plasma glucose levels in alloxan -treated animals. The selective toxicity of alloxn to pancreatic $\beta$ - cells is due to its direct effect on islet cell permeability (Szkudelski,2001).

These results due to that barely and germinated barely are a major source of cereal fibers ( $\beta$-Glucan) that apparently have different effects on glucose metabolism. Because of the retarding effect of soluble fiber on gastric emptying and absorption thus relieving insulin demand. In addition,the intake of these fibers stimulated the acute secretion of glucose-dependent insulinotropic polypeptide .Eating whole grain such as barely and germinated barely improve insulin sensitivity by lowering the glycemic index of the diet while increasing its content of fibers. Evidences suggest that dietary fiber from whole grains may be responsible for some of the beneficial health effects Behall et al. (2004), Marciani et al. (2001) and McMullen (2000). 
Table 2. Change of rats body weight after treatment of normal and germinated barely products

\begin{tabular}{|c|c|c|c|c|c|c|c|c|c|c|c|c|c|c|c|c|c|c|}
\hline weeks & Control (-) & $\begin{array}{c}\text { Body } \\
\text { weight } \\
\text { incr. } \\
(\%)\end{array}$ & $\begin{array}{c}\text { Control } \\
(+)\end{array}$ & $\begin{array}{c}\text { Body } \\
\text { weight } \\
\text { decr. } \\
(\%)\end{array}$ & $\begin{array}{c}\text { D+ normal } \\
\text { barely } \\
\text { bread }\end{array}$ & $\begin{array}{c}\text { Body } \\
\text { weight } \\
\text { decr. } \\
(\%)\end{array}$ & $\begin{array}{c}D+ \\
\text { germinate } \\
\text { d barely } \\
\text { bread }\end{array}$ & $\begin{array}{c}\text { Body } \\
\text { weight } \\
\text { decr. } \\
(\%)\end{array}$ & $\begin{array}{c}\text { D+ normal } \\
\text { barely } \\
\text { biscuits }\end{array}$ & $\begin{array}{c}\text { Body } \\
\text { weight } \\
\text { decr. } \\
(\%)\end{array}$ & $\begin{array}{c}\text { D+ } \\
\text { germinated } \\
\text { barely } \\
\text { biscuits }\end{array}$ & $\begin{array}{l}\text { Body } \\
\text { weight } \\
\text { decr. } \\
(\%)\end{array}$ & $\begin{array}{l}\text { Normal } \\
\text { talbina }\end{array}$ & $\begin{array}{c}\text { Body } \\
\text { weight } \\
\text { decr. } \\
(\%)\end{array}$ & $\begin{array}{l}\text { Germinated } \\
\text { talbina }\end{array}$ & $\begin{array}{c}\text { Body } \\
\text { weight } \\
\text { decr. } \\
(\%)\end{array}$ & $\mathbf{F}$ & $\mathbf{p}$ \\
\hline $1^{\text {st }}$ week & $150.0 \pm 0.10$ & & $180.0 \pm 0.49$ & & $187.0 \pm 0.12$ & & $198.0 \pm 0.09$ & & $187.0 \pm 0.06$ & & $199.0 \pm 0.51$ & & $185.0 \pm 0.08$ & & $199.0 \pm 0.07$ & & $3830.206^{*}$ & $<0.001$ \\
\hline $2^{\text {nd }}$ week & $155.0 \pm 0.11$ & 3.33 & $175.0 \pm 0.12$ & 2.78 & $180.0 \pm 0.31$ & 3.74 & $188.0 \pm 0.22$ & 5.05 & $182.0 \pm 0.42$ & 2.67 & $196.0 \pm 0.28$ & 1.51 & $183.0 \pm 0.00$ & 1.08 & $195.0 \pm 0.30$ & 2.01 & $2601.179^{*}$ & $<0.001$ \\
\hline $3^{\text {rd }}$ week & $165.0 \pm 0.26$ & 10.00 & $165.0 \pm 0.31$ & 8.33 & $175.0 \pm 0.25$ & 6.42 & $179.0 \pm 0.23$ & 9.60 & $177.0 \pm 0.05$ & 5.35 & $190.0 \pm 0.49$ & 4.52 & $180.0 \pm 0.05$ & 2.70 & $187.0 \pm 0.38$ & 6.03 & $981.690^{*}$ & $<0.001$ \\
\hline $4^{\text {th }}$ week & $175.0 \pm 0.25$ & 16.67 & $160.0 \pm 0.27$ & 11.11 & $170.0 \pm 0.16$ & 9.09 & $177.0 \pm 0.34$ & 10.61 & $175.0 \pm 0.25$ & 6.42 & $187.0 \pm 0.27$ & 6.03 & $175.0 \pm 0.49$ & 5.41 & $180.0 \pm 0.28$ & 9.55 & $664.819^{*}$ & $<0.001$ \\
\hline
\end{tabular}

\#: number of rats $(\mathrm{n}=3)$

$\mathrm{F}$ : F for ANOVA test

$\mathrm{p}$ : $\mathrm{p}$ value for comparing between the studied groups

*: Statistically significant at $\mathrm{p} \leq 0.05$

Each value is expressed as mean \pm SE; [(week X - week 0)/week 0] X 100\%. 


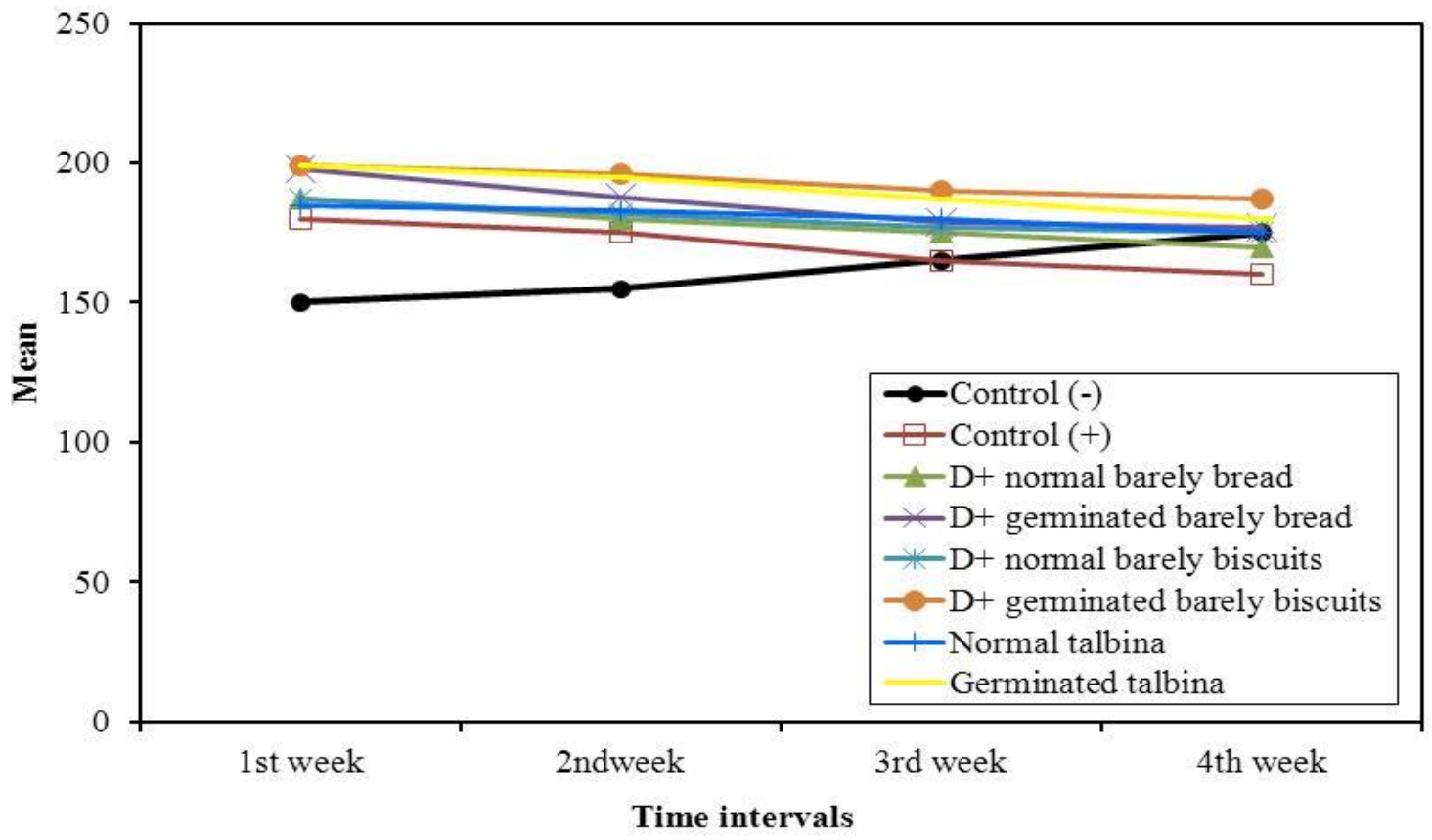

Figure 1. change of rats body weight after treatment of normal and germinated barely products.

Table 3. Changes in serum glucose level,insulin level of diabetic and non diabetic rats fed on normal and germinated barely

\begin{tabular}{lcc}
\hline Treatment groups & Glucose (mg/d) & Insulin (mIU/L) \\
\hline Control (-) & $81.0^{\mathrm{b}} \pm 3.21$ & $2.47^{\mathrm{a}} \pm 0.64$ \\
Diabetic rats & $230.0^{\mathrm{a}} \pm 18.93$ & $0.35^{\mathrm{d}} \pm 0.08$ \\
D +barely bread & $98.33^{\mathrm{b}} \pm 7.51$ & $0.58^{\mathrm{cd}} \pm 0.17$ \\
D +Germinated barely bread & $95.0^{\mathrm{b}} \pm 5.77$ & $0.89^{\mathrm{bcd}} \pm 0.27$ \\
D +barey biscuits & $86.33^{\mathrm{b}} \pm 3.28$ & $1.34^{\mathrm{bc}} \pm 0.24$ \\
D +germinated barely biscuits & $85.33^{\mathrm{b}} \pm 8.67$ & $1.47^{\mathrm{bc}} \pm 0.27$ \\
D + Talbina & $80.0^{\mathrm{b}} \pm 5.0$ & $1.42^{\mathrm{bc}} \pm 0.36$ \\
D +germinated talbina & $74.33^{\mathrm{b}} \pm 2.19$ & $1.80^{\mathrm{ab}} \pm 0.17$ \\
F & $37.095^{*}$ & $4.554^{*}$ \\
P & $<0.001^{*}$ & $0.006^{*}$ \\
LSD 5\% & 25.397 & 0.955 \\
\hline
\end{tabular}

Data was expressed using Mean $\pm \mathrm{SE}$.

F: F for ANOVA test, Pairwise comparison bet. each 2 groups was done using Post Hoc Test (LSD)

Means in the same column with common letters are not significant (i.e. Means with Different letters are significant)

$\mathrm{p}$ : $\mathrm{p}$ value for comparing between the studied groups

*: Statistically significant at $\mathrm{p} \leq 0.05$.

D:diabetic rats

$\beta$-glucan, a soluble fiber found in barley, has been shown to reduce glycemia (Tosh, 2013). Different physiological effects of $\beta$-glucan in isolated form or as a constituent of barley products are related to its viscosity: attenuation of postprandial plasma glucose and insulin responses, high transport of bile acids

towards lower parts of the intestinal tract and high excretion of bile acids or lowering of serum cholesterol levels (Sadiq Butt et al., 2008). Johansson (2006) demonstrated that barley $\beta$-glucans are plant polysaccharides resistant to digestion and absorption in 
the small intestine, and they attenuate both blood glucose and cholesterol.

Effect of normal and germinated barely products on Lipid profile of diabetic Rats

The data in Table (4) revealed significant $(\mathrm{p} \leq 0.05)$ increment in triglycerides, cholesterol, LDL-C, VLDL-C in diabetic rats as compared with the negative control. In contrast, the HDL-C level in diabetic rats was found to be significantly higher than that in the negative control. It is worth to note that the diabetic rats treated on germinated products exhibited significant changes in the aforementioned atherogenic indices being close to positive control rat. Germinated talbina improved significantly the level of total lipids, triglycerides, and cholesterol. On the other hand, feeding rats on germinated and normal products resulted in a significant improvement in HDL and LDL as compared to the negative control. The LDL-C/ HDL-C is much better predictor for risk of heart disease than LDL-C alone. The LDL-C/ HDL-C reflects the two way traffic of cholesterol entering and leaving the arterial intima (Fernandez-Orozco et al., 2003).

Data presented here confirm the conclusions of Youssef et al (2006) that barely product can be useful, at least as an adjunct, in the therapy of diabetes, a condition in which hyperglycemia and hyperlipidemia coexist quite often. These effects of barley could be caused by water soluble mixed-linkage $\beta$-glucan and its viscosity (Hassan, 2019). Moreover, Lattimer and Haub (2010), stated that, a potential mechanism for $\beta$ - glucan inhibition of weight gain is through its gel-forming effect, which may delay gastric emptying and reduce or delay the digestion/ absorption of macronutrients. The cholesterol-lowering effects of germinated barely have been attributed to the $\beta$-glucan fractions in humans (Othman et al., 2011) and animals (Delaney et al., 2003; Immerstrand et al., 2010 and Bae et al., 2010).

Several mechanisms have been proposed for the hypocholesterolemic effect of $\beta$-glucan including increasing viscosity of intestinal contents and reduced absorption of dietary cholesterol and reabsorption of bile acids (Lund et al., 1989); increasing binding of luminal bile acids by $\beta$ - glucan thereby decreasing enterohepatic circulation of bile acids with subsequent increased hepatic uptake of circulating cholesterol for bile acids synthesis; or reducing hepatic cholesterol synthesis secondary to improved insulin sensitivity (Bell et al., 1999); and inhibiting hepatic cholesterol synthesis by acetate (Karlsson et al., 2013) and propionate (Zhang et al., 2012) produced by colonic bacteria fermentation of soluble fibers. Our results are in greement of the results of Othman et al., 2011\& Delaney et al., 2003; Immerstrand et al., 2010 and Bae et al., 2010 who reported that the cholesterol-lowering effects of barely have been attributed to the $\beta$-glucan fractions in humans and animals. The present study concluded that germinated talbina is recommended especially for people with diabetic mellitus because of its effect on lowering glucose and lipid profile.

Table 4. Changes lipid profile of diabetic (D) and non -diabetic in rats fed on normal and germinated barely in serum

\begin{tabular}{lcccc}
\hline Treatment groups & Cholesterol $(\mathbf{m g} / \mathbf{d l})$ & T.G $(\mathbf{m g} / \mathbf{d l})$ & HDL $(\mathbf{m g} / \mathbf{d l})$ & LDL $(\mathbf{m g} / \mathbf{d l})$ \\
\hline Control (-) & $69.33^{\mathrm{c}} \pm 6.33$ & $73.0^{\mathrm{b}} \pm 6.08$ & $35.67^{\mathrm{a}} \pm 1.86$ & $19.07^{\mathrm{c}} \pm 5.69$ \\
Diabetic rats & $126.0^{\mathrm{a}} \pm 6.66$ & $170.0^{\mathrm{a}} \pm 26.66$ & $19.67^{\mathrm{c}} \pm 1.20$ & $72.33^{\mathrm{a}} \pm 6.20$ \\
D +barely bread & $84.67^{\mathrm{b}} \pm 3.18$ & $89.67^{\mathrm{b}} \pm 11.32$ & $27.33^{\mathrm{b}} \pm 1.45$ & $39.40^{\mathrm{b}} \pm 3.58$ \\
D +germinated barely bread & $85.67^{\mathrm{b}} \pm 1.76$ & $104.67^{\mathrm{b}} \pm 5.70$ & $30.33^{\mathrm{ab}} \pm 1.33$ & $41.40^{\mathrm{b}} \pm 3.36$ \\
D +barey biscuits & $84.0^{\mathrm{b}} \pm 4.73$ & $83.67^{\mathrm{b}} \pm 4.81$ & $30.33^{\mathrm{ab}} \pm 1.20$ & $36.93^{\mathrm{b}} \pm 4.82$ \\
D +germinated barely biscuits & $85.0^{\mathrm{b}} \pm 3.61$ & $87.0^{\mathrm{b}} \pm 1.73$ & $33.33^{\mathrm{a}} \pm 3.18$ & $34.47^{\mathrm{b}} \pm 1.88$ \\
D + Talbina & $80.0^{\mathrm{bc}} \pm 4.36$ & $72.33^{\mathrm{b}} \pm 8.29$ & $33.67^{\mathrm{a}} \pm 1.33$ & $31.87^{\mathrm{bc}} \pm 4.98$ \\
D +germinated talbina & $75.33^{\mathrm{bc}} \pm 4.84$ & $72.0^{\mathrm{b}} \pm 4.62$ & $32.33^{\mathrm{ab}} \pm 2.03$ & $28.60^{\mathrm{bc}} \pm 6.50$ \\
F & $13.249^{*}$ & $8.318^{*}$ & $7.642^{*}$ & $10.236^{*}$ \\
P & $<0.001^{*}$ & $<0.001^{*}$ & $<0.001^{*}$ & $<0.001^{*}$ \\
LSD 5\% & 14.04 & 33.931 & 5.4278 & 14.561 \\
\hline
\end{tabular}

Data was expressed using Mean $\pm \mathrm{SE}$.

F: F for ANOVA test, Pairwise comparison bet. each 2 groups was done using Post Hoc Test (LSD)

Means in the same column with common letters are not significant (i.e. Means with Different letters are significant)

$\mathrm{p}$ : $\mathrm{p}$ value for comparing between the studied groups

*: Statistically significant at $\mathrm{p} \leq 0.05$. 


\section{REFERENCES}

Alkhatib, A., C.Tsang, A.Tiss, T.Bahorun, H. Arefanian, R.Barake and J.Tuomilehto. 2017. Functional Foods and Lifestyle Approaches for Diabetes Prevention and Management. Nutrients, 9(12), 1310.

Asgary, S. 2011. Hypoglycaemic and hypolipidemic effects of pumpkin (Cucurbita pepo L.) on alloxan-induced diabetic rats. African Journal of Pharmacy and Pharmacology, 5(23):2620-2626.

Bae, I. Y., S. M.Kim, S. Lee and H. G. Lee. 2010. Effect of enzymatic hydrolysis on cholesterol-lowering activity of oat beta-glucan. New biotechnology, 27(1): 85-88.

Behall, K. M., D. J.Scholfield and J.Hallfrisch. 2004. Diets containing barley significantly reduce lipids in mildly hypercholesterolemic men and women. The American journal of clinical nutrition, 80(5) :1185-1193.

Bell, S., V. M.Goldman, B. R. Bistrian, A. H.Arnold, G.Ostroff and R. A. Forse. 1999.Effect of beta-glucan from oats and yeast on serum lipids. Critical reviews in food science and nutrition, 39(2): 189-202.

Brockman, D. A., X.Chen and D. D. Gallaher. 2013. Consumption of a high $\beta$-glucan barley flour improves glucose control and fatty liver and increases muscle acylcarnitines in the Zucker diabetic fatty rat. European journal of nutrition, 52(7):1743-1753.

Chawla, A., R.Chawla and S. Jaggi. 2016. Microvasular and macrovascular complications in diabetes mellitus: distinct or continuum? Indian journal of endocrinology and metabolism, 20(4): 546-551.

Coles, L. 2014. Functional foods: The connection between nutrition, health and food science. New Jersey: Apple Academic Press.

Defronzo, R. A. 1997. Pathogenesis of type 2 diabetes: metabolic and molecular implications for identifying diabetes genes. Diabetes reviews, 5: 177-266.

Delaney, B., R. J.Nicolosi, T. A.Wilson, T.Carlson, S. Frazer, G. H. Zheng and N.Knutson. 2003. Beta-glucan fractions from barley and oats are similarly antiatherogenic in hypercholesterolemic Syrian golden hamsters. The Journal of nutrition, 133(2):468-475.

Fernandez-Orozco, R., H. Zieliński and M. K. Piskuła. 2003. Contribution of low-molecular-weight antioxidants to the antioxidant capacity of raw and processed lentil seeds. Die Nahrung, 47(5): 291-299.

Fossati, P., and L. Prencipe. 1982. Serum triglycerides determined colorimetrically with an enzyme that produces hydrogen peroxide. Clinical chemistry, 28(10): 2077-2080.

Hassan, D. R. 2019. Effects of oat and barley on some biochemical parameters in hyperglycemic rats and their effects on rheological and sensory attributes of baked bread. Journal of Studies and Searches of Specific Education, 2(1):201-218.
Hughes, T. A., J. T.Gwynne, B. R.Switzer, C.Herbst and G.White. 1984. Effects of caloric restriction and weight loss on glycemic control, insulin release and resistance, and atherosclerotic risk in obese patients with type II diabetes mellitus. The American journal of medicine, 77(1):7-17.

Jaye, M., K.-a. T.Doan, J. A. Krawiec, K. J.Lynch, D. V Amin, V. J. South and D. J. Rader. 2009. Compositions and Methods for Effecting the Levels of High Density Lipoprotein (HDL) Cholesterol and Apolipoprotein AI, Very Low Density Lipoprotein (VLDL) Cholesterol and Low Density Lipoprotein (LDL) Cholesterol, Patent Application 12/197,970. United State: Aventis Pharmaceuticals Inc.

Johansson, L. 2006. Structural analyses of $(1 \rightarrow 3),(1 \rightarrow 4)-\beta-D-$ glucan of oats and barley (Ph.D Thesis). University of Helsinki, Finland.

Karlsson, F., V.Tremaroli, J.Nielsen and F. Bäckhed. 2013. Assessing the human gut microbiota in metabolic diseases. Diabetes, 62(10):3341-3349.

Kaukovirta-Norja, A., A.Wilhelmson and K. Poutanen. 2004. Germination: a means to improve the functionality of oat. Agric Food Sci, 13: 100-112.

Kirkpatrick, L.A. and B.C. Feeney. 2013.A simple guide to IBM SPSS statistics for version 20.0. Student ed. Belmont, Calif.: Wadsworth, Cengage Learning

Li, L., M.Pan, S.Pan, W. Li, Y. Zhong, J. Hu and S.Nie. 2020. Effects of insoluble and soluble fibers isolated from barley on blood glucose, serum lipids, liver function and caecal short-chain fatty acids in type 2 diabetic and normal rats. Food and Chemical Toxicology, 135, 110937.

Lopes-Virella, M. F., P. G.Stone and J. A. Colwell. 1977.Serum high density lipoprotein in diabetic patients. Diabetologia, 13(4): 285-291.

Lott, J. A., and K.Turner. 1975. Evaluation of Trinder's glucose oxidase method for measuring glucose in serum and urine. Clinical chemistry, 21(12):1754-1760.

Lund, E. K., J. M.Gee, J. C. Brown, P. J. Wood and I. T. Johnson. 1989. Effect of oat gum on the physical properties of the gastrointestinal contents and on the uptake of D-galactose and cholesterol by rat small intestine in vitro. The British journal of nutrition, 62(1):91-101.

Marciani, L., P. A.Gowland, R. C.Spiller, P. Manoj, R. J. Moore, P.Young and A. J. Fillery-Travis.2001. Effect of meal viscosity and nutrients on satiety, intragastric dilution, and emptying assessed by MRI. American journal of physiology. Gastrointestinal and liver physiology, 280(6): G1227-1233.

Martirosyan, D. M. and J.Singh. 2015. A new definition of functional food by FFC: what makes a new definition unique? Functional foods in health and disease, 5(6):209-223.

McMullen, M. S. 2000. Oats. In M. Dekker (Ed.), Handbook of cereal science and technology (p.p. 127-140). New York: Routledge. 
Mohajeri, D., G.Mousavi and Y.Doustar. 2009. Antihyperglycemic and pancreas-protective effects of crocus sativus 1.(saffron) stigma ethanolic extract on rats with alloxan-induced diabetes. Journal of Biological Sciences, 9(4): 302-310.

Montonen, J., P. Knekt, R. Järvinen, A.Aromaa and A. Reunanen. 2003. Whole-grain and fiber intake and the incidence of type 2 diabetes. The American journal of clinical nutrition, 77(3):622-629

Niva, M. 2007. 'All foods affect health': understandings of functional foods and healthy eating among healthoriented Finns. Appetite, 48(3): 384-393.

Nonogaki, H., G. W.Bassel, and J. D. Bewley.2010. Germination-still a mystery. Plant Science, 179(6): 574-581.

Othman, R. A., M. H.Moghadasian, and P. J. Jones. 2011. Cholesterol-lowering effects of oat $\beta$-glucan. Nutrition reviews, 69(6):299-309.

Pejcz, E., A.Czaja, A. Wojciechowicz-Budzisz, Z. Gil and R. Spychaj. 2017. The potential of naked barley sourdough to improve the quality and dietary fibre content of barley enriched wheat bread. Journal of Cereal Science, 77:97101.

Quanhong, L., F.Caili, R.Yukui, H.Guanghui and C. Tongyi. 2005. Effects of protein-bound polysaccharide isolated from pumpkin on insulin in diabetic rats. Plant foods for human nutrition (Dordrecht, Netherlands), 60(1):13-16.

Saba, N. H. 1991.[Cooking is ascience and Art]. Alexandria: Dar-El Maaref.

Sadiq Butt, M., M.Tahir-Nadeem, M. K. Khan, R.Shabir and M. S. Butt. 2008. Oat: unique among the cereals. European journal of nutrition, 47(2):68-79.

Slavin, J. L., D. Jacobs and L.Marquart. 2001. Grain processing and nutrition. Critical reviews in biotechnology, 21(1):49-66.

Stocker, R., and J. F. Jr. Keaney. 2004. Role of oxidative modifications in atherosclerosis. Physiological reviews, 84(4):1381-1478.
Suresh, Y., and U. N. Das. 2006. Differential effect of saturated, monounsaturated, and polyunsaturated fatty acids on alloxan-induced diabetes mellitus. Prostaglandins, leukotrienes, and essential fatty acids, 74(3):199-213.

Szkudelski, T. 2001. The mechanism of alloxan and streptozotocin action in $\mathrm{B}$ cells of the rat pancreas. Physiological research, 50(6):537-546.

Tosh, S. M. 2013. Review of human studies investigating the post-prandial blood-glucose lowering ability of oat and barley food products. European journal of clinical nutrition, 67(4):310-317.

Tripathi, B. K., and A. K. Srivastava. 2006. Diabetes mellitus: complications and therapeutics. Medical science monitor, 12(7):Ra130-147.

World Health Organization [WHO]. 2016. Global report on diabetes. Geneva: Switzerland: WHO.

XueMin, X., and C. Jue. 2001. Study of extraction and isolation of effective pumpkin polysaccharide component and its reducing glycemia function. Chinese Journal of Modern Applied Pharmacy, 18:662-664.

Yousef, M. I. 2006. Biochemical and immunological study on the effects of barley and its components as hypoglycemic agents in diabetic rats. American Journal of Biochemistry and Biotechnology, 2:1-8.

Youssef, H. 2008. Nutritional assessment of telbina and telbina fortified biscuits. Home Economics, 18: 3-14.

Youssef, M. K. E., F. El-Fishawy, E.Ramadan and A.Abd ElRahman. 2013. Nutritional Assessment of Barley, Talbina and Their Germinated Products. Frontiers in Science, 3(2):56-65.

Zeng, Y., X.Pu, J. Du, X.Yang, X.Li, M. S. N. Mandal and J.Yang. 2020. Molecular Mechanism of Functional Ingredients in Barley to Combat Human Chronic Diseases. Oxidative medicine and cellular longevity, 3836172

Zhang, P. P., X. Z. Hu, H. M.Zhen, C.Xu and M. T. Fan. 2012. Oat $\beta$-glucan increased ATPases activity and energy charge in small intestine of rats. Journal of Agricultural and Food Chemistry, 60(39): 9822-9827. 


\section{الملخص العربي}

\section{تأثير تغذية الفئران المصابة بالسكر علي منتجات الثعير العادي المنبت علي الوزن ودهون الام}

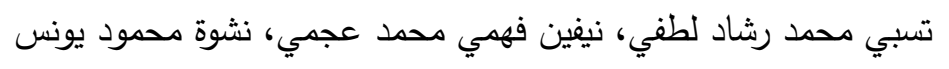

من كل المجاميع وتم فصل السيرم وتقدير معايير دهون الدم.

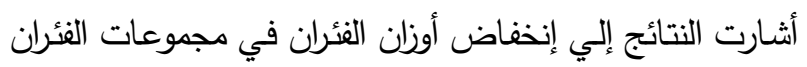

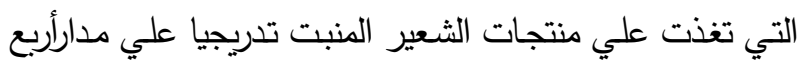

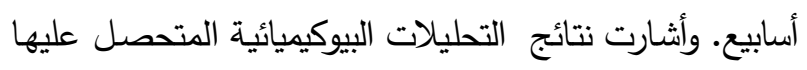

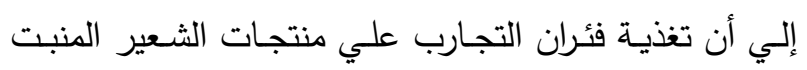

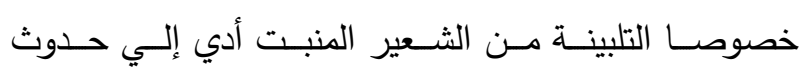

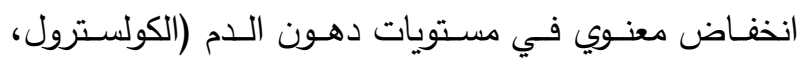

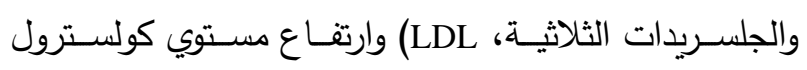

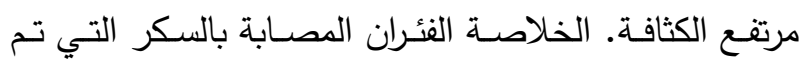

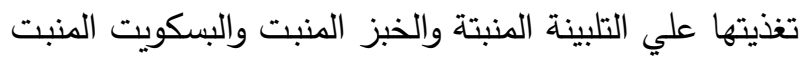
علي التوالي حسنت معايير دهون الدم مقارنة بالمجموعات التئي

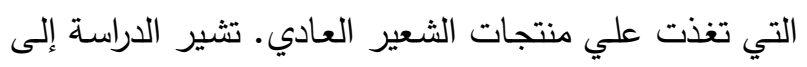

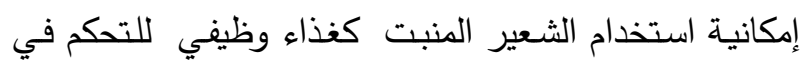
مستوي الجلوكوز في الدم وتحسين صحة الإنسان.

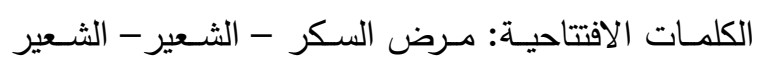
المنبت- التلبينة - دهون الدم.
تهدف الدراسـة إلى تقيـيم تأثير بعض منتجـات الثـعير العادي والمنبت مثل الخبز والبسكويت والتلبينة علي الفئران المصابة بالسكر . استخدم في هذه الدراسة عدد 07 من ذكور الفئران البيضاء البينو تم تقسيمهم إلى مجموعتين رئيسيتين.

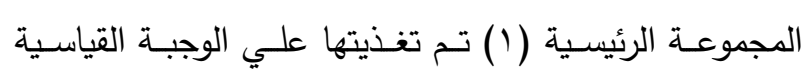

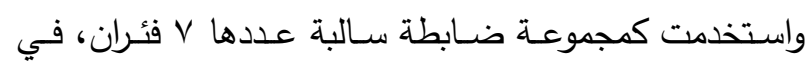

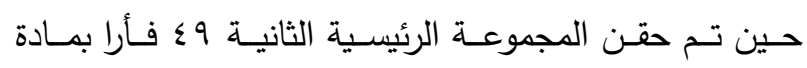

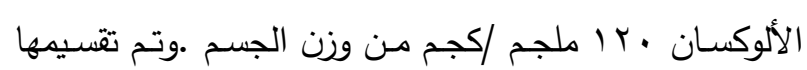

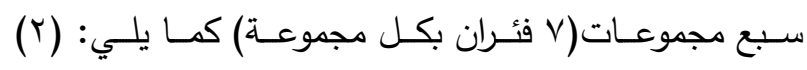
المجموعة الضابطة الموجبة(مصابة بإرتفاع مستوي جلوكوز

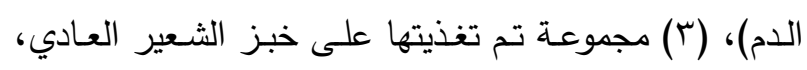

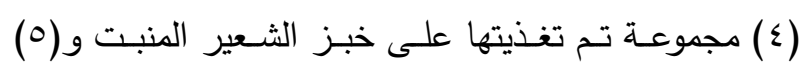

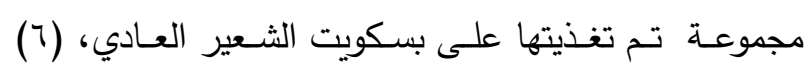

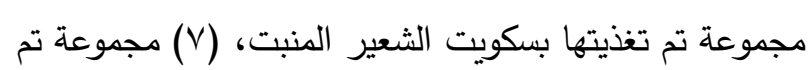

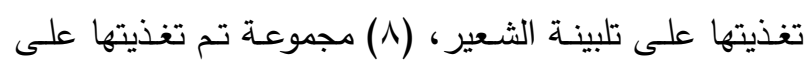

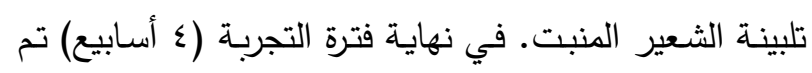

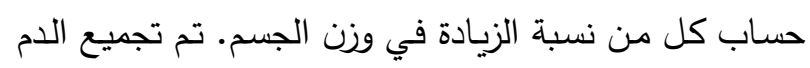

